Supplementary table 1

Consolidated criteria for reporting qualitative studies (COREQ): 32-item checklist

\begin{tabular}{|c|c|c|c|}
\hline No & Item & Guide questions/description & \\
\hline \multicolumn{4}{|c|}{ Domain 1: Research team and reflexivity } \\
\hline \multicolumn{4}{|c|}{ Personal Characteristics } \\
\hline 1. & Interviewer/facilitator & $\begin{array}{l}\text { Which author/s conducted the } \\
\text { interview or focus group? }\end{array}$ & $\begin{array}{l}\text { First author Oyungerel } \\
\text { Byambasuren }\end{array}$ \\
\hline 2. & Credentials & $\begin{array}{l}\text { What were the researcher's } \\
\text { credentials? E.g. PhD, MD }\end{array}$ & MD/GP, MMedRes \\
\hline 3. & Occupation & $\begin{array}{l}\text { What was their occupation at } \\
\text { the time of the study? }\end{array}$ & PhD candidate \\
\hline 4. & Gender & $\begin{array}{l}\text { Was the researcher male or } \\
\text { female? }\end{array}$ & Female \\
\hline 5. & Experience and training & $\begin{array}{l}\text { What experience or training } \\
\text { did the researcher have? }\end{array}$ & Master of Medical Research \\
\hline \multicolumn{4}{|c|}{ Relationship with participants } \\
\hline 6. & Relationship established & $\begin{array}{l}\text { Was a relationship established } \\
\text { prior to study } \\
\text { commencement? }\end{array}$ & No \\
\hline 7. & $\begin{array}{l}\text { Participant knowledge of } \\
\text { the interviewer }\end{array}$ & $\begin{array}{l}\text { What did the participants know } \\
\text { about the researcher? e.g. } \\
\text { personal goals, reasons for } \\
\text { doing the research }\end{array}$ & $\begin{array}{l}\text { Participants were informed } \\
\text { about my overall PhD } \\
\text { objectives and this interview } \\
\text { study aims }\end{array}$ \\
\hline 8. & $\begin{array}{l}\text { Interviewer } \\
\text { characteristics }\end{array}$ & $\begin{array}{l}\text { What characteristics were } \\
\text { reported about the } \\
\text { interviewer/facilitator? } \\
\text { e.g. Bias, assumptions, reasons } \\
\text { and interests in the research } \\
\text { topic }\end{array}$ & $\begin{array}{l}\text { In the Discussion, we report } \\
\text { that the interviewer was not } \\
\text { "pro-apps". She went into this } \\
\text { research on health apps as an } \\
\text { average smartphone owner of } \\
21^{\text {st }} \text { century but not a pro-tech } \\
\text { digital enthusiast per se. }\end{array}$ \\
\hline
\end{tabular}

\title{
Domain 2: study design
}

Theoretical framework

\begin{tabular}{|l|l|l|}
\hline 9. & $\begin{array}{l}\text { Methodological } \\
\text { orientation and Theory }\end{array}$ & $\begin{array}{l}\text { What methodological } \\
\text { orientation was stated to } \\
\text { underpin the study? e.g. } \\
\text { grounded theory, discourse } \\
\text { analysis, ethnography, } \\
\text { phenomenology, content } \\
\text { analysis }\end{array}$ \\
\hline
\end{tabular}

Participant selection

Grounded theory 


\begin{tabular}{|c|c|c|c|}
\hline 10. & Sampling & $\begin{array}{l}\text { How were participants } \\
\text { selected? e.g. purposive, } \\
\text { convenience, consecutive, } \\
\text { snowball }\end{array}$ & Purposive and snowball \\
\hline 11. & Method of approach & $\begin{array}{l}\text { How were participants } \\
\text { approached? e.g.face-to-face, } \\
\text { telephone, mail, email }\end{array}$ & Face-to-face and email \\
\hline 12. & Sample size & $\begin{array}{l}\text { How many participants were in } \\
\text { the study? }\end{array}$ & 20 GPs and 15 patients \\
\hline 13. & Non-participation & $\begin{array}{l}\text { How many people refused to } \\
\text { participate or dropped out? } \\
\text { Reasons? }\end{array}$ & $\begin{array}{l}\text { None of the GPs I approached } \\
\text { refused to participate. Ten } \\
\text { patients refused due to having } \\
\text { no experience and opinion } \\
\text { about health apps. }\end{array}$ \\
\hline \multicolumn{4}{|c|}{ Setting } \\
\hline 14. & Setting of data collection & $\begin{array}{l}\text { Where was the data collected? } \\
\text { e.g. home, clinic, workplace }\end{array}$ & $\begin{array}{l}\text { F2F interviews were done in a } \\
\text { GP clinic. Telephone interviews } \\
\text { mixed }\end{array}$ \\
\hline 15. & $\begin{array}{l}\text { Presence of non- } \\
\text { participants }\end{array}$ & $\begin{array}{l}\text { Was anyone else present } \\
\text { besides the participants and } \\
\text { researchers? }\end{array}$ & No \\
\hline 16. & Description of sample & $\begin{array}{l}\text { What are the important } \\
\text { characteristics of the } \\
\text { sample? e.g. demographic data, } \\
\text { date }\end{array}$ & $\begin{array}{l}\text { We purposively sampled } \\
\text { participants to include all ages } \\
\text { and work experience levels. } \\
\text { Demographic data is reported } \\
\text { in table } 1 \text { in Results section. }\end{array}$ \\
\hline \multicolumn{4}{|c|}{ Data collection } \\
\hline 17. & Interview guide & $\begin{array}{l}\text { Were questions, prompts, } \\
\text { guides provided by the } \\
\text { authors? Was it pilot tested? }\end{array}$ & $\begin{array}{l}\text { Yes and yes. Reported in } \\
\text { Methods section }\end{array}$ \\
\hline 18. & Repeat interviews & $\begin{array}{l}\text { Were repeat interviews carried } \\
\text { out? If yes, how many? }\end{array}$ & No \\
\hline 19. & Audio/visual recording & $\begin{array}{l}\text { Did the research use audio or } \\
\text { visual recording to collect the } \\
\text { data? }\end{array}$ & Audio recorded \\
\hline 20. & Field notes & $\begin{array}{l}\text { Were field notes made during } \\
\text { and/or after the interview or } \\
\text { focus group? }\end{array}$ & Yes \\
\hline 21. & Duration & $\begin{array}{l}\text { What was the duration of the } \\
\text { interviews or focus group? }\end{array}$ & $\begin{array}{l}\text { GP interviews averaged } 12 \\
\text { minutes and patient interviews } \\
4 \text { minutes. }\end{array}$ \\
\hline
\end{tabular}




\begin{tabular}{|c|c|c|c|}
\hline 22. & Data saturation & $\begin{array}{l}\text { Was data saturation } \\
\text { discussed? }\end{array}$ & $\begin{array}{l}\text { Yes. Data was considered } \\
\text { saturated when there was no } \\
\text { new information emerged in } 3 \\
\text { consecutive interviews. }\end{array}$ \\
\hline 23. & Transcripts returned & $\begin{array}{l}\text { Were transcripts returned to } \\
\text { participants for comment } \\
\text { and/or correction? }\end{array}$ & No \\
\hline \multicolumn{4}{|c|}{ Domain 3: analysis and findings } \\
\hline \multicolumn{4}{|c|}{ Data analysis } \\
\hline 24. & Number of data coders & $\begin{array}{l}\text { How many data coders coded } \\
\text { the data? }\end{array}$ & Two \\
\hline 25. & $\begin{array}{l}\text { Description of the coding } \\
\text { tree }\end{array}$ & $\begin{array}{l}\text { Did authors provide a } \\
\text { description of the coding tree? }\end{array}$ & No \\
\hline 26. & Derivation of themes & $\begin{array}{l}\text { Were themes identified in } \\
\text { advance or derived from the } \\
\text { data? }\end{array}$ & $\begin{array}{l}\text { Derived from the data } \\
\text { inductively }\end{array}$ \\
\hline 27. & Software & $\begin{array}{l}\text { What software, if applicable, } \\
\text { was used to manage the data? }\end{array}$ & Microsoft Excel \\
\hline 28. & Participant checking & $\begin{array}{l}\text { Did participants provide } \\
\text { feedback on the findings? }\end{array}$ & No \\
\hline \multicolumn{4}{|c|}{ Reporting } \\
\hline 29. & Quotations presented & $\begin{array}{l}\text { Were participant quotations } \\
\text { presented to illustrate the } \\
\text { themes / findings? Was each } \\
\text { quotation identified? e.g. } \\
\text { participant number }\end{array}$ & Yes, as GPs and Pt (patients) \\
\hline 30. & $\begin{array}{l}\text { Data and findings } \\
\text { consistent }\end{array}$ & $\begin{array}{l}\text { Was there consistency between } \\
\text { the data presented and the } \\
\text { findings? }\end{array}$ & Yes \\
\hline 31. & Clarity of major themes & $\begin{array}{l}\text { Were major themes clearly } \\
\text { presented in the findings? }\end{array}$ & Yes \\
\hline 32. & Clarity of minor themes & $\begin{array}{l}\text { Is there a description of diverse } \\
\text { cases or discussion of minor } \\
\text { themes? }\end{array}$ & Yes \\
\hline
\end{tabular}

